\title{
Taxation as a Means of Migration Control: The Case of Hungary
}

\author{
Luc Leboeuf $^{*}$ \& Alice Pirlot ${ }^{* *}$
}

\section{INTRODUCTION}

On 20 June 2018, the Hungarian parliament passed a law imposing a 'special immigration tax' of $25 \%$ on the financial support provided to Hungarian organizations engaged in so-called 'immigration support activities'. Support for immigration is defined in a broad way, so as to include 'any programme, action or activity that, directly or indirectly, aims at promoting immigration', including but not limited to participation in media campaigns, the building and operation of advocacy networks and other 'propaganda activities that portray immigration in a positive light'. ${ }^{2}$ Immigration is also defined broadly, covering any movement of any alien to Hungary, with the exception of those who benefit from the EU freedom of movement (EU citizens and their family members, as well as citizens of European Economic Area countries and their family members) and those who are the family members of Hungarian nationals. ${ }^{3}$ The tax is due from either the donors or the organizations carrying out the immigration support activities. It was initially proposed as part of the so-called 'Stop Soros' legislative package, the stated aim of which was to protect Hungarian identity in the face of 'mass immigration hitting Europe and the activities of pro-immigration forces'. 4
In his thorough analysis, Daniel Deak highlights the legislative history of the Hungarian tax, its 'corrective' objective and its main characteristics. He also draws attention to the numerous legal issues raised by the tax in terms of proportionality and fundamental rights, as guaranteed by the Hungarian Constitution, primary and secondary provisions of EU law and the European Convention on Human Rights (ECHR).

This article seeks to complement Deak's analysis while adopting a broader perspective. It shows that different types of interactions can arise between taxation and migration policies. Migration leads to tax consequences and, at the same time, taxation can influence migration (section 2). An analysis of the special immigration tax seems to suggest that it is the latest example of a broader policy shift to control migration. Taxation is being used as a means to deal with the aftermath of the so-called 'European migration crisis' of 2015, during which EU Member States struggled to provide a coordinated and efficient response to a sharp increase in the arrival of asylum seekers (section 3). ${ }^{5}$ Although taxation can be a policy instrument to achieve regulatory objectives, the use of taxation to regulate migration is questionable (section 4) and may lead to violations of human rights (section 5).

\section{Notes}

* Research Fellow, Max Planck Institute for Social Anthropology, Department of Law \& Anthropology. This article is financially supported by the Max Planck Society within the framework of the research initiative 'The Challenges of Migration, Integration and Exclusion' (WiMi). Email: leboeuf@eth.mpg.de.

** $\quad$ Research fellow, Oxford University Centre for Business Taxation. Email: Alice.Pirlot@sbs.ox.ac.uk.

1 Disclaimer: the authors do not speak Hungarian. Therefore, their analysis is based on unofficial English translations of Hungarian laws and on information provided by Daniel Deak in the article published in this issue of Intertax. See e.g. HU: Bill T/625 amending certain tax laws and related laws, and on the special tax on immigration, unofficial English translation, https://www.helsinki.hu/wp-content/uploads/t-625.pdf (accessed 13 Dec. 2018); HU: Special Immigration Tax of Act XLI of 2018 amending certain tax laws and other related acts and on a Special Immigration Tax, s. 253, English translation, https://www.venice.coe.int/webforms/documents/?pdf=CDL-REF(2018) 059-e (accessed 13 Dec. 2018).

Special Immigration Tax of Act XLI of 2018, supra n. 1, s. 253(2).

Ibid. The promotion of the immigration of aliens who benefit from 'Section 1 of Act I of 2007 on the Admission and Residence of Persons with the Right of Free Movement and Residence' falls outside of the scope of the tax. An unofficial English translation of that law can be found on Refworld, a database established by the UNHCR, https:// www.refworld.org/docid/4979ca2e2.html (accessed 6 Dec. 2018).

4 General reasoning attached to the Bill, as cited and translated in Venice Commision and OESCE/ODIHR, Hungary - Joint Opinion on the Provisions of the So-Called 'Stop Soros' Draft Legislative Package which directly affect NGOs, Venice Commission Opinion 919/2018 \& OSCE/ODIHR Opinion NGOHUN/326/2018, (25 June 2018), at 4, para. 12, osce.org/odihr/385932? download=true (accessed 10 Dec. 2018).

5 Also sometimes referred to as the 'European refugee crisis'. As emphasized by various authors, this 'crisis' also resulted from the deficiencies of the Common European Asylum System. M. den Heijer, J. Rijpma \& T. Spijkerboer, Coercion, Probibition and Great Expectations. The Continuing Failure of the Common European Asylum System, $53(3)$ Com. Mkt. L.Rev. 607-642 (2016); H. Labayle, La crise des politiques européennes d'asile et d'immigration, regard critique, 5 Revue française de droit administratif 893 (2017); D. Thym, The Refugee Crisis as a Challenge of Legal Design and Institutional Legitimacy, 53(6) Com. Mkt. L. Rev. 1545-1573 (2016). 


\section{TAXATION AND MIGRATION}

Deak describes the Hungarian special immigration tax as 'unique in the history of fiscal policy'. He is right, in that no other country - to the best of the authors' knowledge - has introduced a similar and specific levy on donations to organizations advocating migrants' rights. Yet - and as Deak also recognizes in the first sections of his article, interactions between taxation and migration policies are neither new nor unique. Tax systems have always had to respond to the mobility of taxpayers. Because the notion of 'residence' plays an essential role in the determination of the scope of personal and corporate income tax systems, most tax systems react to migration.

In other instances, tax systems have sought to directly influence migration. It is not uncommon for countries to provide preferential tax regimes to new residents so as to encourage their immigration. As countries often use their corporate income tax to attract foreign direct investment, they also regularly use their tax systems to attract so-called 'high net worth' individuals. ${ }^{6}$ For example in some countries, new wealthy residents are fully exempt from inheritance and gift taxes. In other countries, they may benefit from low tax rates on their personal income. These special tax regimes are usually linked to residence schemes benefiting individuals who are ready to significantly invest in their new residence country (so-called 'golden visas'). ${ }^{7}$ Some countries go so far as to reward substantial investment with citizenship (so-called 'golden passports'), a practice that has raised concerns within the EU, as it has the corollary effect to award EU citizenships and grant access to the freedom of movement within the EU. Hungary offered a 'golden visa' programme until 2017.'

Finally, in some instances, tax systems indirectly interact with migration through the adoption of specific tax measures aimed at supporting relief activities. Some countries have introduced special tax exemptions for institutions that provide help to asylum seekers, or reduced VAT rates for the supply of services to asylum seekers. ${ }^{10}$
These measures do not intend to 'react to' or to 'directly influence' migration as defined above. Instead, they adapt the tax system to support private actors who assist the state in the fulfilment of its legal duties towards asylum seekers. They offer indirect financial support to those who relieve the state of some of the costs linked with the exercise of state prerogatives - in that case the fulfilment of international obligations towards asylum seekers.

The Hungarian special immigration tax provides an example of a new type of indirect interaction between taxation and migration issues. Hungary is seeking to indirectly influence (viz. discourage) migration to its territory by means of its tax system through the imposition of a tax on organizations engaged in immigration support activities. Taxation is then used as a means to control migration, as considered below.

\section{TAXATION AND MIGRATION CONTROL}

The use of taxation as an instrument of migration control fits within a larger policy shift in Europe. It is one of the latest developments in the constant search for new means to ensure state control over migration. Since the end of the 1990s, the change in the nature and importance of migration flows resulting from increasing mobility patterns in the context of globalization has led European states to develop sophisticated policy and legal constructions to control migration. These include the drafting of agreements with third countries to control migrants before they reach the jurisdiction of European states (externalization) ${ }^{11}$ and the criminalization of behaviours that facilitate irregular migration, including smuggling $^{12}$ (criminalization). ${ }^{13}$ Taxation thus appears as the latest addendum to the legislative and policy arsenal aimed at controlling migration.

The Hungarian government is not the first to use its tax system to discourage migration. In 2017, Belgium modified its income tax code to exclude asylum seekers from the possibility of receiving the child tax credit (maximum EUR 450 per child per taxable year). ${ }^{14}$ The

\section{Notes}

OECD, Engaging with High Net Worth Individuals on Tax Compliance (OECD Publishing 2009).

A. Scherrer \& E. Thirion, Citizenship by Investment (CBI) and Residency by Investment (RBI) Schemes in the EU: State of Play, Issues and Impacts, Study of the European Parliamentary Research Service, PE 627/128 (Oct. 2018). The report lists the following countries as 'particularly attractive to non-EU investors': Bulgaria, Cyprus, Estonia, Ireland, Italy, Latvia, Malta, Portugal (at 17). They provide high net worth individuals with special access to residency or citizenship in combination with preferential tax regimes.

8 Scherrer \& Thirion, supra n. 7.

Ibid., at 16 .

10 See among others, the regimes in place in Lebanon to (i) exempt wages of nurses working in asylum seekers reception centres from the personal income tax and (ii) exempt asylum seekers reception centres from the corporate income tax. R. Hamzaoui, Lebanon - Individual Taxation and Corporate Taxation, IBFD Country Surveys, s. 1. (accessed 4 Dec. 2018). See also the lower VAT rate for 'asylum services' in Turkey. B. Yalt1, Turkey - Corporate Taxation, IBFD Country Surveys, s. 8. (accessed 4 Dec. 2018),

11 M. Maes, D. Vanheule, J. Wouters \& M.-C. Foblets, The International Dimensions of EU Asylum and Migration Policy: Framing the Issues, in External Dimensions of EU Migration and Asylum Law and Policy 9-60 (M. Maes, M.-C. Foblets \& P. De Bruycker eds, Bruylant 2011); R. Zaiotti, Mapping Remote Control: The Externalization of Migration Management in the 21st Century, in Externalizing Migration Management: Europe, North America and the Spread of 'Remote Control' Practices (R. Zaiotti ed., Routledge 2016).

12 E.g. Council Directive 2002/90/EC of 28 Nov. 2002 defining the facilitation of unauthorised entry, transit and residence, OJ L328/17 (5 Dec. 2002), at 17.

13 V. Mitsilegas, The Criminalisation of Migration in Europe. Challenges for Human Rights and the Rule of Law (Springer 2015).

14 BE: Art. 3 Law of 25 Dec. 2016, published 30 Dec. 2016, modifying Arts 4 \& 243/1 of the Income Tax Code. Art. 234/1, $1^{\circ}$ bis of the Income Tax Code was further modified in 2017 (by Art. 124, a) L. 25 Dec. 2017 and Art. 63 L. 18 Feb. 2018). This provision no longer includes a direct reference to Art. 4, $4^{\circ}$ of the Income Tax Code (which clarifies the scope of application of the personal income tax on asylum seekers). 
objective, as stated in the preparatory works, was to clarify the existing legal framework so as to explicitly prevent asylum seekers from being considered as 'tax residents' in Belgium and being granted the benefit of the child tax credit. ${ }^{15}$ Some MPs pointed towards the immoral character of the measure, which affects asylum seekers who are amongst the most vulnerable population. ${ }^{16}$ Others defended the measure and insisted on the administrative implementation costs resulting from the allocation of the tax credit to asylum seekers, drawing attention to its fiscal - rather than moral - aspects. ${ }^{17}$ The Minister of Finance presented the measure as a 'matter of principle', emphasizing that it was not aimed at raising revenue. $^{18}$ Seven NGOs (including UNICEF Belgium) sought to annul the reform before the Constitutional Court. ${ }^{19}$ That case is still pending. The claim is mainly based on the principle of equality and non-discrimination. ${ }^{20}$ It is argued that the reform has a stigmatizing effect on asylum seekers, as there is no reasonable justification for a differentiated treatment of asylum seekers. ${ }^{21}$ Moreover, the measure has been described as useless, as most asylum seekers did not effectively benefit from the child tax credit. ${ }^{22}$

Both the Belgian and Hungarian tax regimes show an evolution in the interactions between taxation and migration policies. The tax system does not only react to migration, but also attempts to control migration. Where, in the past, the proactive role of the tax system was mainly aimed at attracting high net worth individuals, tax measures are now also being used to discourage the immigration of those who do not fall into that category and whose economic and social value to the host society is less straightforward and often open to debate. Migration is then treated as a human activity that entails external social and economic costs, which should be internalized through taxation. Assuming that such use of the tax system to differentiate between migrants according to their revenue would be ethical and in conformity with international and EU law, which the authors doubt for the reasons presented in section 5 , the discussion below questions the extent to which tax policies may be used to pursue the regulatory objective of controlling migration.

\section{TAXATION AND THE INTERNALIZATION OF SO-CALLED MIGRATION EXTERNALITIES}

The main goal of taxation is to raise revenue to fund public expenditures. However, taxation can also be used to achieve regulatory objectives, by either encouraging or discouraging certain behaviours. ${ }^{23}$ Some of the most common reasons to choose taxation over regulatory measures in order to pursue regulatory goals are based on economic arguments. It is argued that tax measures can achieve regulatory goals in a more cost-effective way than non-economic regulatory measures. This justification is often raised in the field of environment policies where tax measures might be preferred over regulations in order to internalize the 'social costs' of polluting activities in accordance with the 'polluter pays' principle. ${ }^{24}$ Similarly, tax measures can be used to encourage activities that generate positive externalities (e.g. by means of tax incentives).

At first sight, the rhetoric of the Hungarian government suggests that its special immigration tax is justified on economic grounds, in particular the theory of the internalization of externalities (the so-called Pigouvian theory, named after the economist Arthur Pigou). Indeed, the special immigration tax seems to be aimed at internalizing the costs that would result from donations to organizations engaged in so-called activities supporting immigration. ${ }^{25}$ The Hungarian government describes the tax base (namely the amount of the donation or the costs incurred while carrying out the immigration support activities) and tax rate $(25 \%)$ as in line with the effects generated by immigration support activities'. ${ }^{26}$ Moreover, the tax revenue will be earmarked to fund border protection activities - which also indicates that the tax is aimed at internalizing the costs supposedly associated with immigration. $^{27}$

\section{Notes}

15 BE: Draft bill [Projet de loi modifiant les articles 4 et 243/1 du Code des impôts sur les revenus 1992, Doc. 54, 2199/01, at 5; Proposition de loi modifiant le Code des impôts sur les revenus 1992 en ce qui concerne le bénéfice du crédit d'impôt durant la procédure d'asile, Doc. 54, 1547/01, at 4].

16 BE: Legislative Report on the Draft Bill [Rapport de la Première lecture, Doc. 54, 2199/002] in particular at 6-7.

17 Ibid.

18 Ibid., at 8 .

19 Request 6699, submitted on the 27 June 2017 to the Belgian Constitutional Court, Belgian Official Journal on 10 Aug. 2017 , at 78428.

20 BE: Service Droit des Jeunes, Press Release, 7 associations attaquent une loi fiscale odieuse (27 June 2017).

21 Ibid.

22 Ibid.

23 Avi-Yonah provides an overview of how taxation can be used as a form of regulation. R. S. Avi-Yonah, Taxation as Regulation: Carbon Tax, Health Care Tax, Bank Tax and Other Regulatory Taxes, Law \& Economics Working Papers, Paper 21 (2010).

24 D. Fullerton, A. Leicester \& S. Smith, Environmental Taxes, in Dimensions of Tax Design (Institute for Fiscal Studies Mirlees Review 2010), https://www.ifs.org.uk/ publications/7184 (accessed 12 Dec. 2018).

25 Bill T/625 amending certain tax laws and related laws, and on the special tax on immigration, supra n. 1, Detailed Reasoning underlying the tax.

26 Ibid.

27 Ibid. 
The design of the Hungarian tax and the justifications put forward by the Hungarian government suggest that the special immigration tax relies on two main assumptions. First, the activities of organizations active in the field of migration have the effect of attracting migrants to Hungary. Second, migration imposes a burden on the Hungarian budget. ${ }^{28}$ None of these assumptions seem to rest on strong economic arguments. As highlighted by various migration theories, migration results from a complex set of intertwined factors and dynamics. ${ }^{29}$ The Hungarian government presents no evidence to establish that the activities of organizations advocating migrants' rights is a major pull factor that substantially contributes to migration and the associated costs, to the extent that donations to these organizations should be taxed. ${ }^{30}$ Second, the economic and social effects of migration are complex and difficult - if not impossible - to ascertain. Some studies do, however, tend to show that, over time, migrants integrate in the labour market and thus contribute to the creation of economic wealth. ${ }^{31}$

The weaknesses of the assumptions underlying the Hungarian special immigration tax indicate that the tax cannot be - convincingly - justified by the traditional rationale underlying Pigouvian taxes, contrary to what has been argued by the Hungarian authorities. The design of the tax also seems to contradict its alleged objectives. The special immigration tax is not only imposed on donations to organizations active in Hungary, but also to donations made to organizations which have their seat in Hungary but which are active elsewhere. Even if one were to accept that donations to organizations engaged in so-called immigration support activities generate costs, it is difficult to see how and why the Hungarian government could justify a tax on externalities that are generated outside its territory. $^{32}$

The question therefore arises as to whether the choice by Hungary to use taxation as part of its policy mix to control migration could be justified on other (non-economic) grounds. Policy makers could opt for taxation because it offers a larger degree of flexibility to disincentivize undesirable behaviours than non-economic regulatory measures (e.g. if the measure is not effective in modifying taxpayer behaviour, the tax rate could be increased to place additional pressure on taxpayers). In contrast, non-economic regulatory instruments offer legislators two main options, which consist in either the prohibition of undesirable behaviours (e.g. a ban on certain vehicles that are considered too polluting) or the imposition of standards (e.g. energy efficiency standards on electrical appliances). Policy makers may also choose to adopt regulations over tax or economic measures - or vice versa - due to legal constraints, based on either institutional legal grounds (e.g. voting requirements) or substantial legal grounds (e.g. constitutional provisions protecting certain rights).

On the one hand, policy makers sometimes favour the use of regulations over tax measures for the simple reason that the former can be easier to adopt than the later. For example at the EU level, the Treaties require unanimity in the field of taxation, while qualified majority voting requirements apply in many other fields. ${ }^{33}$ On the other hand, policy makers may favour the use of tax measures because they are more likely to conform to constitutional rights and human rights. For example, past case law of the European Court of Human Rights (ECtHR) indicates that, under certain circumstances, fines or the withdrawal of a tax advantage may constitute a proportionate interference in the freedom of association in instances where the forced dissolution or a ban on certain of activities would not. ${ }^{34}$ In other words, tax measures may more easily pass the proportionality test because they offer a greater degree of flexibility than a regulatory ban. Yet, institutional or substantial legal grounds to resort to taxation are debatable, as they are unrelated to the pursued policy objective. Indeed, the form of the regulatory instrument (a tax or a non-economic regulation) is primarily justified by the constraints of the legal framework.

Although the Hungarian government refers to the theory on the internalization of social costs to justify its tax measure, its decision to adopt a tax on donations to organizations engaged in immigration support activities seems to have been motivated, at least in part, by such

\section{Notes}

28 The unofficial translation of the detailed reasoning justifying the Hungarian tax measure refers to the 'costs which arose because the activities of some particular organizations resulted in an increase in immigration as well as an increase in the State's tasks and expenses'. Ibid.

29 For a summary, see V. Piché, Contemporary Migration Theories as Reflected in their Founding Texts, 68(1) Population 141-164s (2011).

30 Quantifying the external costs of human activities is arguably always a difficult task, and regulatory taxes should not be disregarded simply because the determination of the 'right' tax burden to be imposed on activities that generate negative externalities is a complex endeavour. However, if a tax is aimed at internalizing externalities, policy makers should better rely on strong evidence as to the reality of the alleged negative externalities (even if these externalities cannot be precisely quantified).

31 OECD, Indicators of Immigrant Integration 2015: Settling in (OECD Publishing 2015).

32 If one accepts the reasoning of the Hungarian government (according to which organizations active in Hungary generate negative externalities in Hungary), one could even argue that donations to organizations active in other countries could have reverse - positive - effects on Hungary (as these organizations will attract migrants to other countries, which in turn could reduce the 'pressure' on Hungary).

33 A concrete example where the institutional framework significantly influenced the choice of a regulatory instrument over a tax is the EU Emission Trading Scheme (EU ETS), which is one of the key EU policies aimed at internalizing carbon emissions. One of the reasons why the European Union adopted a trading scheme (namely an economic regulatory scheme) rather than a carbon tax is mainly to be explained by EU institutional rules. As Member States could not unanimously agree on the introduction of a carbon tax, the second-best option was to introduce the EU ETS.

34 ECtHR: 22 Nov. 2010, Jehovah's Witnesses of Moscow and others v. Russia, App. 302/02, at 159, referred to in the Joint Opinion of the Venice Commission of the Council of Europe and of the Office for Democratic Institutions and Human Rights of the OSCE, supra n. 4, at fn. 52. 
attempt to escape substantial legal constraints. A ban on organization carrying out immigration support activities would immediately have raised concerns in terms of human rights. This suggests that the justification underlying the Hungarian tax is debatable. This also implies that the tax needs to be assessed under human rights law provisions, and in particular the freedom of expression and of association. That analysis is undertaken below.

\section{TAXATION, MIGRATION CONTROL AND HUMAN RIGHTS}

The special immigration tax is part of the Stop Soros legislative package. It was adopted together with another law that criminalizes assistance to asylum seekers by subjecting it to punishment of up to one year imprisonment. Numerous concerns were raised by international institutions, such as the Organization for Security and Co-operation in Europe (OSCE) and the Council of Europe. ${ }^{35}$ The European Commission launched infringement proceedings $^{36}$ and the ECtHR was petitioned by a Hungarian NGO that also complained about a broader intimidation campaign through public statements by government officials and administrative harassment. ${ }^{37}$ Both procedures are pending.

One of the main concerns is that the special immigration tax and the concomitant measures will have a significant chilling effect on civil society organizations. NGOs may refrain from advocating for a diverse society which remains open to migration, or even to engage in relief activities that could somehow benefit migrants, in order to avoid being prosecuted and/or finding themselves in financial trouble. The tax could also discourage media and scientific institutions from reporting facts and data on migration, thus affecting the right of the public to receive information. ${ }^{38}$ This is particularly troubling given that migration is a highly divisive and topical issue attracting major attention and concern among European public opinions. As seen above and highlighted by Deak, the negative economic and social externalities of migration are contested, to say the least. ${ }^{39}$ The UN Global Compact for Safe, Orderly and Regular Migration, which Hungary did not sign, therefore calls on states to 'Collect and utilize accurate and disaggregated data as a basis for evidence-based policies'. ${ }^{40}$ Even assuming that such negative externalities could and would be established, migration is a societal issue that raises fundamental ethical questions and should therefore be open to democratic debate.

From a human rights perspective, the potential effects of the Hungarian tax on civil society organizations, media organizations and scientific institutions could imply that the Hungarian tax amounts to interference with the exercise of the rights to freedom of expression and association. Assuming that such an interference exists, it would not likely be justified. The Hungarian government does not seem to pursue a legitimate aim, nor make use of proportionate means. On the contrary, the goals underlying the special immigration tax seem to go against the international and EU legal framework surrounding the protection of migrants' rights.

The Hungarian tax seems to disregard the fact that the advocacy discourse of organizations defending migrants' rights is based, at least in part, on the existing international and EU legal framework. Migrants are not without rights. They are entitled to a variety of human rights protections of varying levels and importance, depending on their legal status. Refugees enjoy a (relatively) extensive set of rights compared to other regular migrants, who themselves enjoy more rights than those who are staying irregularly and ought to be returned. Refugees - namely those who are fleeing persecution as defined in the 1951 Geneva Convention - benefit from a specific framework of international protection established by the 1951 Geneva Convention, which is based on various principles such as non-discrimination. ${ }^{41}$ They are entitled to a strong protection status, which is also guaranteed and developed in various EU secondary provisions. ${ }^{42}$ Regular migrants other than refugees also benefit from a protection framework at the EU level, where the conditions to benefit from a residence permit on account of family reunification and other grounds related to studies or the realization of an economic activity, have been harmonized. Refugees and other regularly staying migrants should be treated 'fairly'

\section{Notes}

35 Joint Opinion of the Venice Commission of the Council of Europe and of the Office for Democratic Institutions and Human Rights of the OSCE, supra n. 4, at 4, para. 12.

36 European Commission, Press Release, Migration and Asylum: Commission Takes Further Steps in Infringement Procedures Against Hungary (19 July 2018), europa.eu/rapid/pressrelease_IP-18-4522_en.htm (accessed 10 Dec. 2018).

7 The petition is available on: helsinki.hu/wp-content/uploads/Application_HHC_25_percent.pdf (accessed 12 Oct. 2018).

3 E.g. ECtHR: 23 Sept. 1994, Jersild v. Denmark, App. 15890/89, para. 31.

9 Supra s. 3, in particular fn. 31.

UN Global Compact for Safe, Orderly and Regular Migration (13 July 2018), objective 1.

41 UNHCR, Convention Relating to the Status of Refugees (28 July 1951), Preamble (also known as the 1951 Refugee Convention); J. Hathaway, The Rights of Refugees Under International Law (Cambridge U. Press 2005).

42 EU Qualification Directive: Directive 2011/95/EU of the European Parliament and of the Council of 13 Dec. 2011 on standards for the qualification of third-country nationals or stateless persons as beneficiaries of international protection, for a uniform status for refugees or for persons eligible for subsidiary protection, and for the content of the protection granted, OJ L337/9 (20 Dec. 2011), at 9-26. The Qualification Directive also establishes a 'subsidiary protection status' for aliens who do not qualify as refugees but are nonetheless fleeing serious human rights violations, due to a situation of indiscriminate violence notably. 
and benefit from a 'vigorous integration policy (which) should aim at granting them rights and obligations comparable to those of EU citizens'. ${ }^{43}$ As for irregularly staying migrants, the Return Directive requires EU Member States to respect their fundamental rights, such as the right to emergency healthcare pending removal.

The special immigration tax fails to distinguish between refugees, regularly staying migrants and irregularly staying migrants and to account for the legal commitments of the Hungarian state towards them. The law is drafted in such unclear and all-encompassing terms that the tax could potentially be imposed even on organizations limiting their activities to informing the broader public on existing international and EU legal commitments. It also risks being used to target international organizations like the UN High Commissioner for Refugees (UNHCR), the international mandate of which is to develop the international legal and policy framework on refugee protection and to ensure the effective implementation of existing international obligations towards refugees. ${ }^{44}$ Moreover, the special immigration tax and concomitant measures could also be regarded as a violation of the EU law principle of sincere cooperation and of the international law principle of good faith because they will limit the possibility to effectively assert legal arguments based on EU and international law. ${ }^{45}$ The common policy on asylum, migration and border control and the equilibrium it establishes between human rights considerations and efficient border controls is indirectly threatened by those measures, as the possibility to take arguments from EU law in the public discourse is being restricted.

Lastly, the tax could be problematic under the nondiscrimination principle. The economic arguments advanced by the Hungarian authorities to justify the special immigration tax are inconsistent (as explained above) and do not explain why activities supporting migration are being targeted in such a broad way. The alleged costs associated by the Hungarian authorities with migration do not fundamentally differ in nature from those resulting from the fulfilment of other state moral and legal duties towards the most vulnerable. All social integration policies and related solidarity measures have a budgetary impact. Yet, there is no legislation imposing a tax on activities that support other vulnerable persons falling under the jurisdiction of Hungary, such as the unemployed, the disabled, the elderly and all those who suffer from economic disadvantages. On the contrary, the performance of such activities by civil society organizations is often encouraged by tax measures, which acknowledge that they relieve the state from some of the costs associated with social cohesion policies. Hungary's specific emphasis on activities supporting migrants' rights does not seem to rest on objective economic reasons. It gives rise to the - particularly troublesome - concern that the tax may be a way to indirectly pursue the illegitimate objective of silencing those whose views on migration differ from those of the authorities.

\section{Conclusion: tAXATION AS A MEANS OF CONTROLLING THE NARRATIVE ON MIGRATION}

Interactions between migration and taxation policies are not a new phenomenon. States have used tax law in various ways to react to the mobility of taxpayers, to attract certain migrants or even to reward those organizations and individuals which assist the state in fulfilling its duties toward asylum seekers. However, following the socalled European migration crisis of 2015 which prompted some European governments to search for new tools to increase state control over migration, the interactions between taxation and migration policies seem to have taken a new turn. The Hungarian special immigration $\operatorname{tax}$ is indicative of this shift, where taxation is being used as a new instrument to control migration to Europe.

Yet, the use of taxation to achieve certain regulatory objectives is not new. States regularly prefer tax measures over regulations in order to pursue regulatory goals, as the former can be more cost-effective. However, the Hungarian special immigration tax seems to rely on assumptions that are not supported by economic evidence. Moreover, such use of taxation becomes problematic when tax law is used to indirectly achieve regulatory objectives that could not be directly pursued by non-economic regulatory instruments without violating superior norms and principles, such as EU law and the ECHR.

The analysis of the special immigration tax highlights that taxation affects the perception of migration. It has been used to signal a relative openness to some migrants, such as high net worth individuals, and more recently to signify a closeness to others, such as asylum seekers. Taxation then participates in the development of a certain narrative on migration, as it allows the depiction of its economic effects in a positive or negative light. The message sent is of a symbolic nature: Migrants are a cost to society and migration is a burden from which no economic or social gains can be expected.

The Hungarian special immigration tax goes one step further in that direction. Besides building a negative narrative as regards migration, it seeks to take control

\section{Notes}

43 Tampere European Council, Presidency Conclusions (15-16 Oct. 1999), para. 18.

44 Convention Relating to the Status of Refugees (1951), supra n. 41, Art. 35.

45 Art. 4(3) TEU; M. Kotzur, Good Faith (Bona Fide), in Max Planck Encyclopedia of Public International Law (Jan. 2009). 
over that narrative by targeting civil society organizations that express diverging views. Ultimately, the Hungarian tax measure can be perceived as an instrument to increase migration control by means of controlling the public discourse on migration. This raises additional issues in terms of human rights, including free speech and freedom of association. Taxing those who express a divergent view on migration could prevent a pluralistic and facts-based debate on migration, especially when combined with other repressive measures and practices. It could also affect migrants' rights, as protected by instruments of international and EU law.

The special immigration tax thus has several characteristics that are common among unsound and poorly designed tax measures. 